\title{
EDUKASI PERPAJAKAN MEKANISME NORMA PERHITUNGAN PENGHASILAN NETO PADA SISWA SMK 2 TEGAL
}

\author{
Musyafa Al Farizi**, Nurul Mahmudah2, Ghea Dwi Rahmadiane, Anita Karunia4 Arifia \\ Yasmins \\ Politeknik Harapan Bersama; JL. Mataram No.9, Tegal, Telp (0283) 352000 \\ Program Studi D-III Akuntansi, Politeknik Harapan Bersama \\ e-mail: ${ }^{1}$ musyafaalfarizi@yahoo.com
}

\begin{abstract}
Abstrak
Dalam penerimaan pajak saat ini kenyataannya belum sesuai dengan harapan pemerintah, disebabkan karena masih rendahnya pengetahuan dan wawasan perpajakan para Wajib Pajak dari dini. Maka dari itu perlu adanya edukasi tentang perpajakan secara dini dimulai dari calon wajib pajak yaitu para pelajar khususnya tentang Norma Perhitungan Penghasilan Neto (NPPN). Pada kegiatan pengabdian masyarakat ini di fokuskan dalam bentuk pemberian edukasi perpajakan mengenai NPPN, sasaran dalam kegiatan ini adalah siswa-siswi dari SMK Negeri 2 Kota Tegal.

Metode pengabdian masyarakat yang digunakan dengan pendekatan edukatif dan community development . Edukatif dengan memberikan wawasan dan pengetahuan tentang pajak khususnya NPPN. Memberikan edukasi kepada para Siswa- Siswi SMK Negeri 1 Kabupaten Brebes mengenai syarat- syarat dan kriteria Wajib Pajak yang memilih Norma Perhitungan Penghasilan Neto serta kaitannya sebagai warga negara Indonesia. Membuat Form pelatihan perhitungan pajak penghasilan wajib pajak yang memilih Norma Perhitungan Penghasilan Neto.

Diharapkan dengan adanya edukasi dan pelatihan ini siswa-siswi SMK N 2 Tegal yang kelak menjadi wajib pajak bisa mengerti kewajibannya menjadi wajib pajak. Dengan adanya wawasan dan edukasi sejak dini tentang pajak maka diharapkan penerimaan negara dari sektor pajak juga semakin meningkat. Penerimaan negara dari sektor pajak yang meningkat maka akan berdampak pada baiknya pembangunan nasional seperti infrastruktur negara Republik Indonesia khususnya.
\end{abstract}

Kata kunci-NPPN, Edukasi, Penerimaan Pajak, Infrastruktur.

\section{PENDAHULUAN}

Pajak adalah pungutan wajib yang dibayar rakyat untuk negara dan akan digunakan untuk kepentingan pemerintah dan masyarakat umum. Rakyat yang membayar pajak tidak akan merasakan manfaat dari pajak secara langsung, karena pajak digunakan untuk kepentingan umum, bukan untuk kepentingan pribadi. Pajak merupakan salah satu sumber dana pemerintah untuk melakukan pembangunan, baik pemerintah pusat maupun pemerintah daerah. Pemungutan pajak dapat dipaksakan karena dilaksanakan berdasarkan undang-undang (Mardiasmo, 2011). 
Dalam penerimaan pajak saat ini kenyataannya belum sesuai dengan harapan pemerintah, disebabkan karena masih rendahnya pengetahuan dan wawasan perpajakan para Wajib Pajak dari dini. Maka dari itu perlu adanya edukasi tentang perpajakan secara dini dimulai dari calon wajib pajak yaitu para pelajar khususnya tentang Norma Perhitungan Penghasilan Neto (NPPN) . Pada kegiatan pengabdian masyarakat ini di fokuskan dalam bentuk pemberian edukasi perpajakan mengenai NPPN, sasaran dalam kegiatan ini adalah siswa-siswi dari SMK Negeri 2 Kota Tegal.

Permasalahan utama pada pelaksanaan pengabdian masyarakat ini adalah NPPN yang sudah diterapkan bagi wajib pajak yang memiliki pekerjaan bebas dan kegiatan usaha. Selain itu memiliki kriteria dengan omset atau peredaran usaha selama setahun kurang dari Rp 4.800.000.000 serta memilih menggunakan norma bukan pembukuan. Namun masih banyak wajib pajak yang khususnya dimaksud dalam kriteria di atas belum mengerti apa dan kegunaan NPPN tersebut.

Hal ini juga yang menuntut institusi / lembaga pendidikan khususnya siswa-siswi SMK Negeri 2 Kota Tegal sebagai calon wajib pajak harus mengetahui edukasi tentang NPPN dan bisa menghitung serta menyampaikan Surat Pemberitahuan (SPT)

Formulir 1770. Dalam pelaksanaan kegiatan pengabdian masyarakat ini yang kaitannya berupa edukasi diharapkan agar siswa-siswi di SMK Negeri 2 Kota Tegal mampu memahami apa itu perpajakan dan bagaimana mekanismenya terkait NPPN sebagai langkah kedepannya untuk dapat diterapkan dalam kehidupan nyata.

\section{METODE}

\subsection{Sasaran Kegiatan PKM}

Target yang diharapkan dari adanya kegiatan pengabdian masyarakat ini adalah adanya komunitas sharing dan consulting tentang perkembangan ilmu perpajakan bagi siswa-siswi SMK Negeri 2 Tegal, mahasiswa, Guru SMK Negeri 2 maupun dosen. Adanya bentuk-bentuk pelatihan berupa kemampuan perpajakan dalam menghitung NPPN. Dengan diadakannya edukasi dan pelatihan ini diharapkan dapat memberikan wawasan tentang pajak mulai dari usia dini yakni anak SMK N 2 Tegal yang kelak menjadi wajib pajak. Diharapkan dengan adanya edukasi dari dini maka mereka wajib pajak bisa mengerti hak dan kewajiban pajaknya.

\subsection{Metode Kegiatan}

Metode pendekatan pembelajaran yang dilakukan dalam kegiatan Pengabdian Masyarakat ini adalah berupa pendekatan edukatif dan community development. Yaitu pendekatan yang memberikan pendidikan kepada siswa-siswi SMK $\mathrm{N} 2$ Tegal mengandung unsur pendidikan yang dapat mendinamisasikan serta menuju kemajuan yang dicita-citakan, serta melakukan pendekatan berorientasi kepada upaya-upaya pengembangan pemberdayaan dengan menjadikan siswa-siswi sebagai subyek dan sekaligus obyek pembangunan dan melibatkan mereka secara langsung.

\subsection{Tahapan Kegiatan PKM}

Adapun solusi yang ditawarkan dalam kegiatan pengabdian ini adalah berupa pelatihan sebagai berikut :

a. Pemetaan (mapping) tentang pemahaman mengenai perpajakan khususnya tentang NPPN bagi Siswa-Siswi SMK Negeri 2 Kota Tegal.

b. Memberikan edukasi kepada para Siswa-Siswi SMK Negeri 2 Kota Tegal mengenai syarat- syarat dan kriteria Wajib Pajak yang memilih NPPN serta kaitannya sebagai warga negara Indonesia. 
c. Membuat Form pelatihan perhitungan pajak penghasilan wajib pajak yang memilih NPPN.

Kegiatan Pengabdian Masyarakat dalam bentuk pemberian Edukasi tentang Norma Perhitungan Penghasilan Neto (NPPN) dilaksanakan sebanyak 2 pertemuan. Pertemuan pertama pada tanggal 03 Agustus 2018 rapat dan persiapan pelaksanaan kegiatan, pertemuan kedua pada tanggal 04 Agustus 2018 pemberian edukasi dan pelatihan perhitungan NPPN. Kegiatan ini dilakukan di ruang Laboratorium Komputer di SMK N 2 Tegal. Adapun tahapan pelaksanaan kegiatan pengabdian ini didokumentasikan pada gambar 1 di bawah ini :

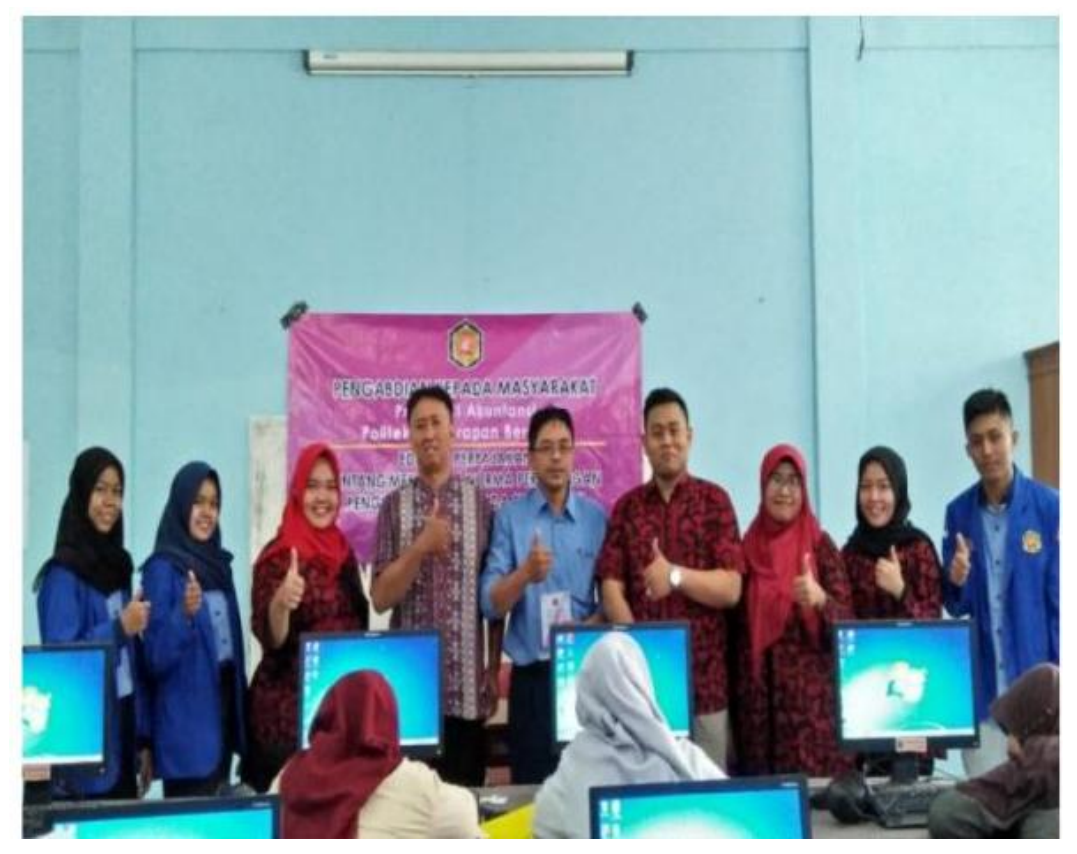

Gambar 1 Pengabdian

\section{HASIL DAN PEMBAHASAN}

Kegiatan Pengabdian Masyarat ini dilaksanakan pada SMK Negeri 2 Kota Tegal. Kegiatan pengabdian masyarakat ini ditujukan guna memberikan edukasi dan wawasan pajak dari dini agar kelak siswa-siswi akan menjadi wajib pajak yang taat akan kewajiban pajaknya. Kegiatan pengabdian masyarakat kali ini merupakan lanjutan dari kegiatan pengabdian masyarakat pada tahun sebelumnya yang diaplikasikan dalam bentuk pelatihan mengenai Perpajakan tentang Pengisian SPT Wajib Pajak (WP) Pribadi Pada Siswa-Siswi SMK Karya Bhakti Kabupaten Brebes. Pelatihan ini di hadiri oleh kurang lebih sekitar 40 siswa-siswi SMK N 2 Kota Tegal.

Kegiatan ini disambut positif oleh pihak Sekolah SMK Negeri 2 Kota Tegal yang bergabung dalam kegiatan pelatihan tersebut, mengapa demikian? Karena pada dasarnya para siswa-siswi sangat membutuhkan pelatihan dan sosialisasi mengenai perpajakan khususnya tentang pengisian Pajak Penghasilan Orang Pribadi dengan menggunakan Norma Perhitungan Penghasilan Neto (NPPN). Hal ini juga dirasakan 
sangat penting, karena banyaknya peraturan-peraturan terbaru tentang pajak yang harus diketahui oleh para siswa-siswi yang kelak akan menjadi Wajib Pajak.

Dalam hal ini kami selaku tim pengabdian kepada masyarakat berharap dengan adanya kegiatan pelatihan mengenai edukasi perpajakan tentang Norma Perhitungan Penghasilan Neto WP Pribadi ini mampu memberikan manfaat dan pemahaman yang sangat mendalam. Hal ini dikhususkan bagi WP Pribadi agar lebih siap dalam menghadapi issue tentang pajak. Kegiatan pengabdian masyarakat ini banyak sekali siswa-siswi yang kreatif memberikan pertanyaan-pertanyaan serta harapan untuk diadakannya tindak lanjut dari kegiatan pelatihan perpajakan berupa bimbingan teknis yang lebih mendalam tentang pelatihan perpajakannya.

Mayoritas diantara peserta dalam kegiatan pengabdian masyarakat ini masih kurang dalam hal wawasan tentang perpajakan. Setelah diberikan edukasi dan wawasan pajak dalam kegiatan pengabdian masyarakat ini, nampak terdapat peningkatan pemahaman oleh siswa-siswi SMK N 2 Tegal. Selain mengerti apa itu NPPN bagi WP Orang Pribadi (OP), peserta juga diberi simulasi bagaimana perhitungan Pajak Penghasilan WP OP yang menggunakan NPPN dengan diberikan beberapa kasus soal yang dikerjakan di kertas kerja yang telah disediakan oleh Tim Pengabdian Masyarakat Politeknik Harapan Bersama.

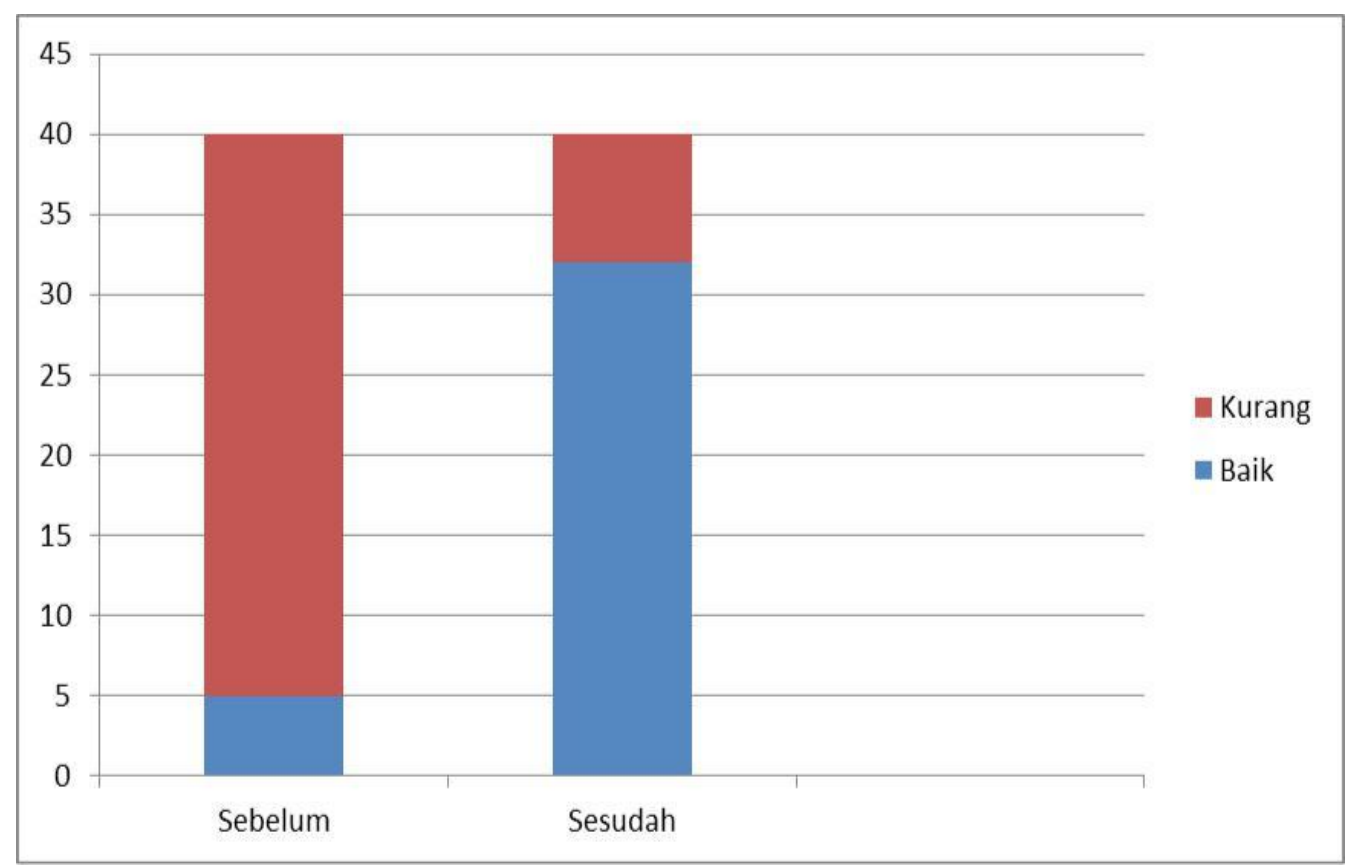

Gambar 2 Grafik peningkatan pengetahuan sebelum dan sesudah penyuluhan

Tabel 1 Perbandingan pengetahuan sebelum dan sesudah penyuluhan

\begin{tabular}{|l|c|c|}
\hline Pengetahuan & Baik & \multicolumn{2}{|l|}{ Kurang } \\
\hline Sebelum penyuluhan & 5 & 35 \\
\hline Sesudah Penyuluhan & 32 & 8 \\
\hline
\end{tabular}




\section{KESIMPULAN}

Edukasi perpajakan yang dilakukan dengan cara penyuluhan adalah salah satu cara untuk memberikan wawasan dan informasi tentang NPPN kepada peserta kegiatan pengabdian ini. Dengan diadakannya edukasi dan pelatihan ini diharapkan dapat memberikan wawasan tentang pajak mulai dari usia dini yakni anak SMK N 2 Tegal yang kelak menjadi wajib pajak. Diharapkan dengan adanya edukasi dari dini maka mereka wajib pajak bisa mengerti hak dan kewajiban pajaknya. Dengan adanya kesadaran dari dini maka diharapkan muncul kesiapan bagi siswa siswi yang diperlukan kelak kalau mereka sudah terjun di dunia usaha sebagai pelaku usaha

\section{SARAN}

Penyuluhan akan perpajakan tentang NPPN Bagi bagi Wajib pajak orang pribadi juga perlu diberikan bagi para pelaku usaha langsung seperti UMKM dan masyarakat umum yang menggunakan NPPN dalam perhitungan kewajiban pajak penghasilannya.

\section{UCAPAN TERIMA KASIH}

Penulis mengucapkan terima kasih kepada Institusi Politeknik Harapan Bersama Tegal Khusus P2M yang telah memberi dukungan financial terhadap kegiatan PKM ini.

\section{DAFTAR PUSTAKA}

[1] Mardiasmo. 2011. "Perpajakan Edisi Revisi 2011”. Yogyakarta : Penerbit Andi

[2] Resmi, Siti. 2017. "Perpajakan : Teori dan Kasus Edisi 10 Buku 1". Jakarta : Penerbit Salemba Empat

[3] Waluyo. 2011. Perpajakan Indonesia. Jakarta: Salemba Empat

[4] Harjanti, R,S., 2017. "Pengisian SPT Wajib Pajak Badan pada Siswa-Siswi SMK Karya Bhakti Kabupaten Brebes”. Tegal : Politeknik Harapan Bersama Tegalhttp://www.pajak.go.id 